\title{
The Negative-Difference Effect during the Localized Corrosion of Magnesium and of the AZ91HP Alloy
}

\author{
Cristina R. Weber, Gerhard Knörnschild* and Luís F. P. Dick
}

\author{
Departamento de Metalurgia, Universidade Federal do Rio Grande do Sul, Av. Osvaldo Aranha, 99, $6^{\circ}$ andar, \\ 90035-190 Porto Alegre- RS, Brazil
}

\begin{abstract}
Foram realizados testes galvanostáticos em soluções de $\mathrm{NaCl}$ com magnésio puro e com a liga AZ91HP, tendo sido medido o volume de hidrogênio desprendido durante os testes. A fim de estudar o efeito da diferença negativa (NDE), uma idéia foi desenvolvida para separar o desprendimento de hidrogênio (H.E) na superfície passiva do desprendimento dentro dos pites. A análise dos dados volumétricos mostrou que a corrente de redução de hidrogênio dentro dos pites, sobre o Mg, é muito mais alta do que nos pites sobre a liga AZ91HP. Supondo que a razão entre a taxa de redução de hidrogênio e a taxa de dissolução de magnésio, expressa pelo fator $k$, não muda com a polarização, foi encontrado um valor de aproximadamente 0,5 para o Mg puro. Para a liga AZ91HP foi alcançado somente um valor em torno de 0,3 .
\end{abstract}

Galvanostatic tests with pure magnesium and with the AZ91HP alloy were performed in $\mathrm{NaCl}$ solutions, and the volume of hydrogen evolved during the tests was measured. In order to examine the negative-difference effect, a concept was developed to separate the hydrogen evolution (H.E.) on the passive surface and the H.E. inside the pits. An analysis of the volumetric data showed that the current density of H.E. inside the pits is much higher for Mg than for the AZ91HP alloy. With the assumption, that the ratio between the hydrogen reduction rate and the rate of the anodic metal dissolution, expressed by the factor $k$, does not change with the polarization, a $k$ value of $c a .0 .5$ for pure Mg was found, while for the AZ91HP alloy this value was only ca. 0.3.

Keywords: magnesium, localized corrosion, AZ91HP alloy, negative-difference effect

\section{Introduction}

The use of magnesium alloys has constantly increased in the last decade due to the increasing demand for energy saving lightweight constructions. However, the poor corrosion resistance of these alloys, especially their susceptibility to localized corrosion, restricts their use in many cases.

\section{Pitting corrosion}

Pitting corrosion is for many alloy/electrolyte systems characterized by the existence of a pitting potential. At this potential the transition between passivity and heavy pitting is marked by a sharp rise in the current densitypotential curve.

Corrosion of magnesium and its alloys has been reported in electrolytes containing anions like $\mathrm{Cl}^{-}, \mathrm{SO}_{4}{ }^{2-}$,

*e-mail: knorri@ppgem.ufrgs.br
$\mathrm{CO}_{3}{ }^{2-}, \mathrm{Br}, \mathrm{ClO}_{4}^{-}, \mathrm{NO}_{3}^{-}$and $\mathrm{PO}_{4}^{3-} \cdot{ }^{3-3}$ Since the passive layer of magnesium is unstable in nearly neutral solutions, the distinction between pitting and general corrosion is sometimes not clear. ${ }^{1}$ Even though, the current densitypotential curves of magnesium and magnesium alloys measured in chloride solutions show usually a pronounced threshold potential, above which the current density rises by several orders of magnitude within a small potential range. ${ }^{2,4,5}$ Galvanostatic tests can therefore be considered as a suitable method for the characterization of the pitting corrosion of magnesium, and were applied in the present work.

Additional potentiodynamic polarization tests can supply informations about pit nucleation from the delayed rise of the current density, when compared with stationary measurements. This effect, which depends strongly on the potential scan rate, can be considered as somewhat analogous to the induction time for pitting in potentiostatic tests. In the present work potentiodynamic tests were performed due to the fact that differences in the 
stationary pitting potential of two materials did not always correctly reflect the differences in the corrosion resistance of these materials.

\section{Negative-difference effect (NDE)}

The corrosion of magnesium and its alloys is accompanied by strong hydrogen evolution and the rate of this reaction has been found to increase with the increase in the anodic polarization. This is usually called the negative-difference effect. Several models have been suggested to explain this effect. The breakdown of a protective film: ${ }^{4,6}$ the hydrogen evolution is attributed to the presence of film-free regions inside the pits. The increase of film-free surface with anodic polarization must overcompensate the decrease of the cathodic current density by anodic polarization. The dissolution of $\mathrm{Mg}$ in two steps: ${ }^{7}$ an electrochemical step $\left(\mathrm{Mg} \rightarrow \mathrm{Mg}^{+}+\mathrm{e}^{-}\right)$ followed by a chemical step in the solution $\left(2 \mathrm{Mg}^{+}+2 \mathrm{H}^{+}\right.$ $\left.\rightarrow 2 \mathrm{Mg}^{2+}+\mathrm{H}_{2}\right)$. In this model, the NDE is due to the increase of the $\mathrm{Mg}^{+}$-concentration by the anodic polarization, which accelerates the hydrogen evolution according to the chemical reaction step. Mass loss and hydrogen evolution by the undermining of second-phase particles (for example the $\beta$-phase $\mathrm{Mg}_{17} \mathrm{Al}_{12}$ ), which consequently fall out, or by some other type of desintegration of the electrode. Secondphase particles are generally cathodic with respect to the Mg-matrix, and this promotes the undermining and fall out of particles by corrosion of the surrounding matrix. This can cause misleading interpretations of mass loss measurements, since the mass loss is due to the mechanical desintegration of the $\mathrm{Mg}$ electrode rather than to the electrochemical dissolution. ${ }^{8-10}$ Formation of magnesium hydride: ${ }^{11-13}$ magnesium hydride can form at sufficiently negative potentials, according to $\mathrm{Mg}+2 \mathrm{H}^{+}+2 \mathrm{e}^{-} \rightarrow \mathrm{MgH}_{2}$. Hydrogen, in this model, is released by the decomposition reaction of the hydride, which is unstable in contact with water: $\mathrm{MgH}_{2}+2 \mathrm{H}_{2} \mathrm{O} \rightarrow \mathrm{Mg}^{2+}+2 \mathrm{OH}^{-}+2 \mathrm{H}_{2}$.

The negative-difference effect is a phenomenon that is also known for other metals, as aluminum, ${ }^{14-16}$ aluminum alloys ${ }^{17}$ and ferrous materials..$^{18}$ In the case of magnesium, however, the investigation of the negative-difference effect is more complex, since the hydrogen gas results from the partial reaction occurring during localized corrosion inside the pits, as well as from the cathodic reaction on the surface outside the pits.

In the case of materials like aluminum or ferrous alloys, pitting takes place only at relatively high potentials, were $\mathrm{H}_{2}$-evolution is slow, or does not occur at all because the applied potential is higher than $\mathrm{E}\left(\mathrm{H}_{2} / \mathrm{H}^{+}\right)$. Hydrogen evolution is then completely attributed to the occurrence of pitting corrosion, with conditions inside the pits that differ from those outside with respect to potential and electrolyte composition. The nucleation of gas bubbles inside the pits has been directly observed in several cases. The pitting potential of $\mathrm{Mg}$ is so negative, that hydrogen is evolved on the entire surface due to the electrochemical decomposition of water. At the same time, hydrogen evolution takes place inside the pits by a reaction, which is obviously coupled with the magnesium dissolution during pitting.

In the present work, hydrogen evolution from pure magnesium and from a MgAlZn alloy (AZ91HP) has been investigated by the volumetric method in $\mathrm{NaCl}$ solutions at the corrosion potential and under galvanostatic anodic polarization. An attempt to calculate the fraction of the hydrogen liberated inside the pits and the fraction that evolves on the surface, outside the pits, separately, was made. Some comparison is made with the pitting corrosion of aluminum alloys, since they show similarities and, moreover, are the most important alternative for Mg-alloys.

\section{Analysis of the NDE by volumetric tests}

The partial reactions occurring inside a pit during the localized corrosion of magnesium are:

$\mathrm{Mg} \rightarrow \mathrm{Mg}^{2+}+2 \mathrm{e}^{-}$

$2 \mathrm{H}^{+}+2 \mathrm{e}^{-} \rightarrow \mathrm{H}_{2}$

Due to the very negative pitting potential, the reduction of hydrogen is also the main cathodic reaction outside the pits:

$2 \mathrm{H}_{2} \mathrm{O}+2 \mathrm{e}^{-} \rightarrow \mathrm{H}_{2}+2 \mathrm{OH}^{-}$

As a consequence, the volume of hydrogen evolved during the corrosion of $\mathrm{Mg}$ in chloride containing solutions is given by the sum of reactions (2) and (3). Assuming that the reduction of oxygen is also a possible reaction, the partial current density of $\mathrm{Mg}$ dissolution, $I_{M g}$, is:

$I_{M g}=I-\left(I_{H_{2} p i t}+I_{H_{2} \text { out }}+I_{O_{2}}\right)$

In a volumetric test the following equation is valid:

$I_{\mathrm{H}_{2} \mathrm{Vol}}=I_{\mathrm{H}_{2} \mathrm{pit}}+I_{\mathrm{H}_{2} \mathrm{out}}$

where $I_{M g}=$ current density of $\mathrm{Mg}$ dissolution, $I_{H_{2 p} i t}=$ current density of hydrogen reduction inside the pits, $I_{H_{2} \text { out }}=$ current density of hydrogen reduction outside the pits, $I_{\mathrm{H}_{2} \mathrm{Vl}}=$ current density of hydrogen reduction obtained 
from volumetric measurements, $I_{\mathrm{O}_{2}}=$ current density of oxygen reduction and $I=$ current density applied in galvanostatic tests.

The rate of hydrogen evolution during the pitting corrosion rises with the anodic polarization of the electrode, which is a characteristic of the negative-difference effect. ${ }^{19}$ In the case of $\mathrm{Al}$ and its alloys, the rate of hydrogen evolution inside the pits was found to be proportional to the rate of metal dissolution, i.e., there exists a factor $k$ defined by: $I_{H_{2} p i t}=-k \bullet I_{A l}$. It has been found for Al, that $k$, which lies between 0.11 and 0.17 , showed only a small dependence on parameters such as chloride concentration, kind of halide ion or alloy composition. ${ }^{17}$ The proportionality between hydrogen evolution and anodic current density has also been reported by Tunold et al. ${ }^{2}$ for Mg and AZ63 alloy at low applied current densities, although it was not accounted for the fraction of hydrogen produced outside the pits. On the basis of this suposition ${ }^{19}$ a similar relationship between the rates of $\mathrm{Mg}$ dissolution and hydrogen evolution inside the pits was assumed in the present work. This leads to the following equation:

$I_{H_{2} p i t}=-k \cdot I_{M g}$

$I_{H_{2} p i t}$ and $I_{M g}$ in this equation are calculated from the respective currents divided by the geometric area of the electrode. The two reactions, indeed, take place at the activated surface inside the pits, which represents only a small part of the geometric surface. The true current densities are therefore much higher, and it was assumed that the magnesium dissolution is entirely caused by pitting corrosion, i.e., occurs inside the pits, while the uniform corrosion outside the pits can be neglected.

Applying equations (6) and (5) to (4), one obtains:

$I_{H_{2} \text { out }}=I-I_{M g} \bullet(1-k)-I_{O_{2}}$

$I_{M g}=I-\left(I_{\mathrm{H}_{2} \mathrm{Vol}}+I_{\mathrm{O}_{2}}\right)$

Applying Equation (4b) to (4a), one obtains:

$I_{\mathrm{H}_{2} \mathrm{out}}=I_{\mathrm{H}_{2} \mathrm{Vol}}+k \cdot\left(I-I_{\mathrm{H}_{2} \mathrm{Vol}}-I_{\mathrm{O}_{2}}\right)$
The equations show that the constant $k$ can be determined from volumetric tests applying different current densities (for example $I=I_{1}=0 \mathrm{~mA} \mathrm{~cm}^{-2}$ at the corrosion potential and $I=I_{2}=1 \mathrm{~mA} \mathrm{~cm}^{-2}$ under galvanostatic polarization). It has been assumed in Equations (4a) and (7) that the current density of hydrogen reduction outside the pits $\left(I_{H_{2} \text { out }}\right)$ remains constant, independent of the applied current densities. This is approximately fulfilled under conditions, where the electrode is nearly unpolarizable, for example for $\mathrm{Mg}$ and the AZ91HP alloy at the pitting potential in $1 \mathrm{~mol} \mathrm{~L}^{-1} \mathrm{NaCl}$ (see Figure 1 and 2). Comparing the data from two galvanostatic tests with the applied current densities $I_{1}$ and $I_{2}$ we obtain the expression for $k$ :

$$
\begin{aligned}
& I_{1 \mathrm{H}_{2} \mathrm{Vol}} \quad k \cdot\left(I_{1}-I_{1 \mathrm{H}_{2} \mathrm{Vol}}-I_{\mathrm{O}_{2}}\right)=I_{2 \mathrm{H}_{2} \mathrm{Vol}}+k \cdot\left(I_{2}-I_{2 \mathrm{H}_{2} \mathrm{Vol}}-I_{\mathrm{O}_{2}}\right) \\
& k=\frac{1}{1-\left(\frac{\Delta I}{\Delta I_{\mathrm{H}_{2} \mathrm{Vol}}}\right)}
\end{aligned}
$$

Where $\Delta I=I_{2}-I_{1}$ and $\Delta I_{\mathrm{H}_{2} \mathrm{Vol}}=I_{2 \mathrm{H}_{2} \mathrm{Vol}}-I_{1 \mathrm{H}_{2} \mathrm{Vol}}$.

\section{Experimental}

The composition of $\mathrm{Mg}$ and the $\mathrm{MgAlZn}$ alloy is shown in Table 1. Specimens of the alloy were cut from an ingot of $7 \mathrm{~cm} \mathrm{x} 14 \mathrm{~cm}$ cross-section, which was used as received.

Galvanostatic tests for the volumetric measurements were made in a conventional electrochemical cell, in air saturated $1 \mathrm{~mol} \mathrm{~L}^{-1}, 0.1 \mathrm{~mol} \mathrm{~L}^{-1}$ and $0.01 \mathrm{~mol} \mathrm{~L}^{-1} \mathrm{NaCl}$ aqueous solutions. The specimens consisted of thin sheets grounded with 600-grit $\mathrm{SiC}$ paper on both sides. To collect the hydrogen gas evolved during the galvanostatic tests, the working electrode was positioned under a burette with a funnel-shaped opening. ${ }^{19}$ Corrections were made for the molecular volume of $\mathrm{H}_{2}$ under test conditions, talking into account the vapor pressure in equilibrium with the test solution and the height of the electrolyte column in the burette.

The following equation was applied:

Table 1. Composition of $\mathrm{Mg}$ and of AZ91HP alloy

\begin{tabular}{lllllllll}
\hline wt.\% & $\mathrm{Al}$ & $\mathrm{Fe}$ & $\mathrm{Mn}$ & $\mathrm{Si}$ & $\mathrm{Zn}$ & $\mathrm{Cu}$ & $\mathrm{Ni}$ & $\mathrm{Mg}$ \\
\hline $\mathrm{Mg}$ & 0.002 & 0.0015 & 0.0015 & 0.0015 & 0.0015 & 0.0004 & - & rest \\
AZ91HP & $8.0-9.5$ & $<0.006$ & $0.10-0.40$ & $<0.06$ & $0.30-1.0$ & $<0.015$ & $<0.001$ & rest \\
\hline
\end{tabular}




$$
V_{m o l}=V_{m o l}^{0} \bullet \frac{T}{T^{0}} \bullet\left(\frac{p^{0}}{p^{0}-\left(\zeta_{s o l} \bullet g \bullet h_{s o l}-p_{H_{2} O}\right)}\right)
$$

with $p^{0}=$ pressure at standard condition, $T^{0}=$ absolute temperature at standard condition, $V_{\text {mol }}^{0}=$ molecular volume at standard condition, $T=$ absolute temperature at test condition $(298 \mathrm{~K}), \zeta_{\text {sol }}=$ density of the test solution, $\mathrm{g}=$ gravity $\left(9.81 \mathrm{~m} \mathrm{~s}^{-2}\right), p_{\mathrm{H}_{2} \mathrm{O}}=$ vapor pressure in equilibrium with the test solution, $h_{\text {sol }}=$ height of the electrolyte column in the burette. This height varied between $50 \mathrm{~cm}$ at the beginning, and about $25 \mathrm{~cm}$ at the end of the tests. This caused a variation of the molecular volume of about $3 \%$ during the test.

The Raman spectra of corroded surfaces of $\mathrm{Mg}$ and AZ91HP alloy were obtained using a Dilor-Jobin Yvon Spectrophotometer. The laser power on the samples was $12 \mathrm{~mW}$, using the $632.82 \mathrm{~nm}$ line of a He-Ne laser. All spectra were recorded from 3 accumulations of $10 \mathrm{~s}$ using a pinhole with a diameter of $1000 \mu \mathrm{m}$ and a filter D0.3.

The specimens used for scanning electron microscopic (SEM) studies of the corrosion attack and for the other electrochemical tests were mechanically polished with diamond paste and with a colloidal silica suspension on one side, while the other sides were covered with lacquer. A closed cell was used, where the solution could be purged with $\mathrm{N}_{2}$ before the beginning of the tests. A platinum grid was used as the counter electrode in all tests and the reference was an $\mathrm{Ag} / \mathrm{AgCl} / 3.5 \mathrm{~mol} \mathrm{~L}^{-1} \mathrm{KCl}$ electrode. Potentiodynamic tests were performed at 0.1, 0.2, 1 and $5 \mathrm{mV} \mathrm{s}^{-1}$. All potentials mentioned in this work are referred to the normal hydrogen electrode (NHE).

\section{Results}

\section{Pitting potentials}

Magnesium and the AZ91HP alloy showed a pitting potential that depends on the logarithm of the chloride ion concentration. The curves were measured by raising the current density after each $8 \mathrm{~min}$, beginning with the lowest value $\left(0.05 \mathrm{~mA} \mathrm{~cm}^{-2}\right)$, and finishing with the highest $\left(10 \mathrm{~mA} \mathrm{~cm}^{-2}\right)$. The pitting potential usually reached a stationary value during these 8 min periods (Figure 1b1). The slope of the stationary galvanostatically measured current density-potential curves decreased with the decreasing chloride concentration. The stationary pitting potential of the $\mathrm{Mg}$ and of the alloy differed by approximately $20 \mathrm{mV}$ (Figure 1a, b).

A larger difference in the corrosion resistance of the two materials was detected in potentiodynamic tests. The onset of the pitting corrosion, i.e., the rise of the current density during the forward scan is more delayed in the case of the AZ91HP alloy (Figures 2a and 2a1) and this effect was more pronounced at slow scan rates, as shown in Figure $2 b$.

The potentiodynamic current density-potential curves obviously revealed differences in the pit nucleation of magnesium and AZ91HP alloy and the pit nucleation seems to be more difficult on the alloy than on the magnesium.
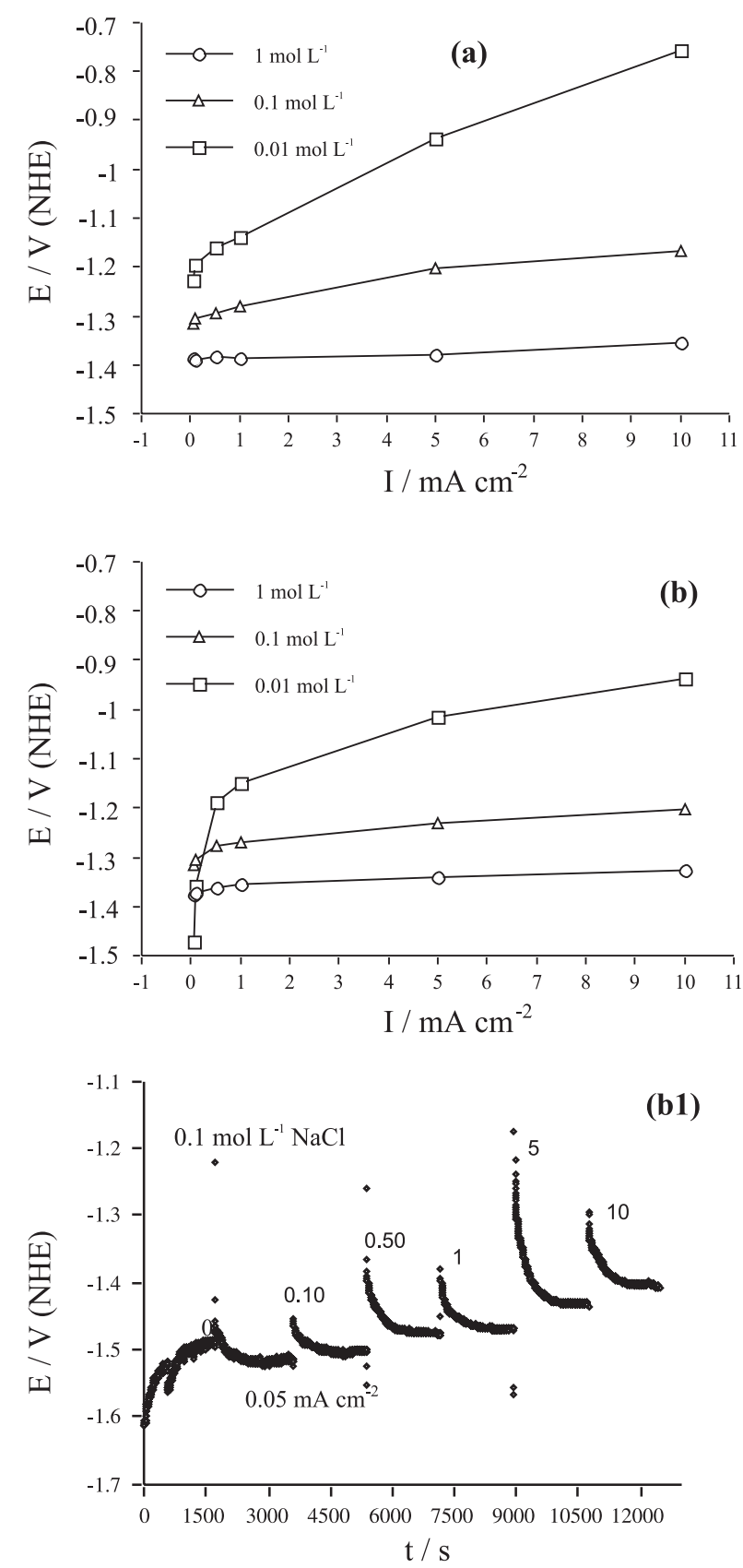

Figure 1. Galvanostatic measurements of the pitting potentials for different chloride concentrations: (a) $\mathrm{Mg}$, and (b) AZ91HP alloy, (b1) current density transients during galvanostatic tests, AZ91HP, $0.1 \mathrm{~mol} \mathrm{~L}^{-1} \mathrm{NaCl}$. 

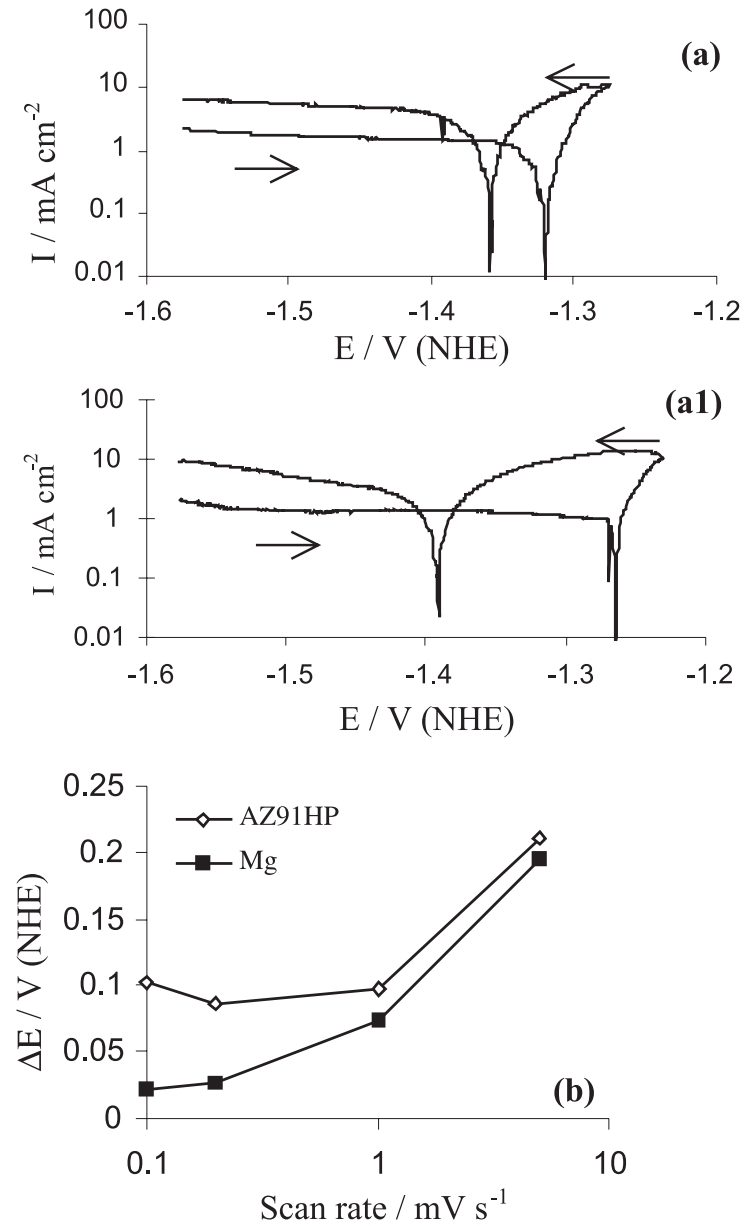

Figure 2. Comparison of the potentiodynamic polarization curves of $\mathrm{Mg}$ and the AZ91HP alloy measured in air-saturated $1 \mathrm{~mol} \mathrm{~L}^{-1}$ $\mathrm{NaCl}$ : (a) $\mathrm{Mg}$ and (a1) $\mathrm{AZ91HP}$, in $0.1 \mathrm{mV} \mathrm{s}^{-1}$ and (b) Difference $\Delta \mathrm{E}$ between galvanostatically measured pitting potential and the potential for reaching $\mathrm{I}=1 \mathrm{~mA} \mathrm{~cm} \mathrm{~cm}^{-2}$ in the forward scan of potentiodynamic tests, as a function of the scan rate.

\section{Influence of the alloying elements}

A linear relationship between the logarithm of the chloride concentration and the stationary pitting potential was found (Figure 3).

The two main alloying elements of the AZ91HP alloy, Al (8-9.5 wt.\%) and Zn (0.3-1 wt.\%), showed little influence on the pitting potential (Figure 3). A comparison with aluminum alloys shows that this also holds for the influence of $\mathrm{Mg}$ on the pitting potential of $\mathrm{Al} .{ }^{20}$ However $\mathrm{Zn}$, when homogeneously dissolved in $\mathrm{Al}$, has a much stronger influence than in the $\mathrm{Mg}$ alloy, as the comparison of $\mathrm{Al}$ and the $\mathrm{AlZn} 3$ alloy ( $3 \mathrm{wt} . \% \mathrm{Zn}$ ) showed. ${ }^{17}$

At a constant current density, the influence of the chloride concentration on the stationary pitting potential can be described by:

$E_{\text {pit }}=E_{\text {pit }}^{0}+$ const $\bullet \log \left[\mathrm{Cl}^{-}\right]$ for $\mathrm{Al}, \mathrm{Mg}$ and its alloys. The constant values for the $\mathrm{Al}$ alloys were between $-70 \mathrm{mV}$ and $-90 \mathrm{mV}$, and for the $\mathrm{Mg}$ alloys were between $-94 \mathrm{mV}$ and $-101 \mathrm{mV}$. However, due to the much lower slopes of the current density-potential curves in $0.01 \mathrm{~mol} \mathrm{~L}^{-1} \mathrm{NaCl}$, the determination of the constant for $\mathrm{Mg}$ and for AZ91HP is more arbitrary.

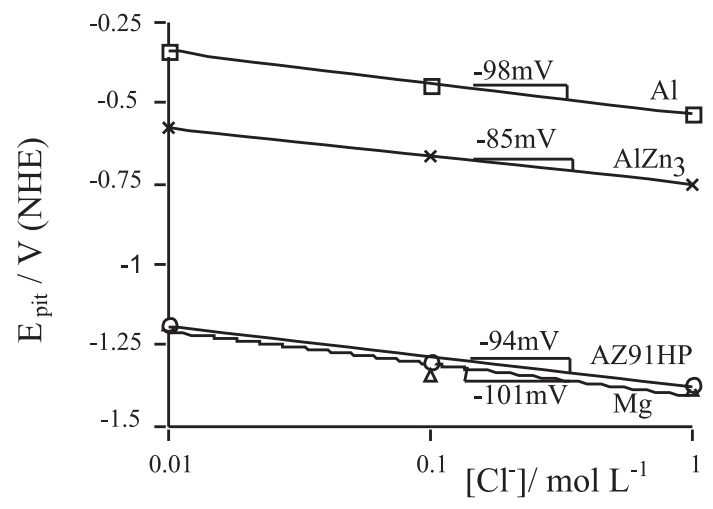

Figure 3. Comparison of the pitting potentials of $\mathrm{Mg}$, AZ91HP alloy, $\mathrm{Al}$ and a homogeneous AlZn3 alloy.

\section{Volumetric tests}

The Figures $4 \mathrm{a}$ and $4 \mathrm{~b}$ show that the rate of hydrogen evolution is generally higher on pure $\mathrm{Mg}$ than on the AZ91HP alloy. It is also higher in the $1 \mathrm{~mol} \mathrm{~L}^{-1} \mathrm{NaCl}$ solution than in the $0.01 \mathrm{~mol} \mathrm{~L}^{-1} \mathrm{NaCl}$ solution. The values of $k$ obtained from equation (8a) with different pairs of applied $I$ and $I_{\mathrm{H}_{2} \mathrm{Vol}}$ measured in $1 \mathrm{~mol} \mathrm{~L}^{-1} \mathrm{NaCl}$, are shown in Table 2 and some scattering of the calculated $k$-values was observed. For the alloy and $\mathrm{Mg}$, the value calculated with $I_{1}=0 \mathrm{~mA} \mathrm{~cm}^{-2}$ and $I_{2}=1 \mathrm{~mA} \mathrm{~cm}^{-2}$ is quite different from the others. This might be due to the fact that the hydrogen evolution under free corrosion conditions was more arbitrary, since the number of pits nucleated during the test and their extension depend on the existence of defects and cathodic sites in the passive film, whereas in the other tests, the nucleation of pits was forced by the applied current. At higher applied current densities the hydrogen reduction inside the pits $I_{H_{2} p i t}$ should become nearly the volumetric measured value $I_{\mathrm{H}_{2} \mathrm{Vol}}$, due to the fact that the hydrogen reduction at the passive surface, $I_{H_{2} \text { out }}$, remains constant, and therefore becomes negligible. Table 2 shows in some cases calculated values of $I_{H_{2} p i t}$, which are slightly higher than $I_{\mathrm{H}_{2} \mathrm{Vol}}$ for AZ91HP at applied current densities of 4,8 and $12 \mathrm{~mA} \mathrm{~cm}^{-2}$. Since $I_{H_{2} p i t}$ can at most be equal to $I_{\mathrm{H}_{2} \mathrm{Vol}}$, this must be due to the uncertainty in the determination of the constant $k$.

It should be pointed out, that $k$ can be determined independent of the value of $I_{\mathrm{O}_{2}}$ and that equation (8a) holds 
under the assumption that $k$ remains constant in the interval between the two applied current densities.

The results are unambiguous with respect to the differences between pure $\mathrm{Mg}$ and the AZ91HP alloy and they show clearly a higher $k$-value for $\mathrm{Mg}$ than for the alloy. This means that by the onset of localized corrosion, the damage is more severe for $\mathrm{Mg}$, because about $50 \%$ of the anodic current is compensated by the hydrogen evolution inside the pits, whereas for AZ91HP alloy this value is only about $30 \%$.

The volumetric tests showed a lower rate of hydrogen evolution in $0.01 \mathrm{~mol} \mathrm{~L}^{-1} \mathrm{NaCl}$ than in $1 \mathrm{~mol} \mathrm{~L}^{-1} \mathrm{NaCl}$, for both $\mathrm{Mg}$ and the alloy. However, for $0.01 \mathrm{~mol} \mathrm{~L}^{-1} \mathrm{NaCl}$, the value of $k$ was not calculated, due to the fact that the current density-potential curves of $\mathrm{Mg}$ and AZ91HP in $0.01 \mathrm{~mol} \mathrm{~L}^{-1} \mathrm{NaCl}$ show a strong polarization, and thus, the precondition of an unpolarizable electrode, necessary for the calculations made in the present work, was not fulfilled.

\section{Microstructure of the alloy}

The microstructure of the AZ91HP alloy consists of Mg-rich $\alpha$-phase (phase A in Figure 5a) and the intermetallic $\beta-\mathrm{Mg}_{17} \mathrm{Al}_{12}$ The $\beta$-phase appears as lamellar eutectic (phase $\mathrm{B}$, in Figure 5a), which contains $\alpha$ and the equilibrium precipitate $\beta-\mathrm{Mg}_{17} \mathrm{Al}_{12}$. As mentioned ${ }^{21-23}$ the occurrence of the lamellar eutectic phase is due to the slow diffusion in the $\mathrm{Mg}$-rich matrix phase during solidification, since the composition of the alloy does not exceed the maximum $\mathrm{Al}$ solubility in the matrix phase. The coring of the $\alpha$-phase was confirmed by EDS-analysis at the center and near the border of the $\alpha$-grains (Figure $5 \mathrm{a}$ : point 1 with $5.8 \mathrm{wt} . \% \mathrm{Al}$, and point 2 with $9.6 \mathrm{wt} . \% \mathrm{Al}$ ). The eutectic phase also appears in the form of a massive $\mathrm{Mg}_{17} \mathrm{Al}_{12}$ compound, which contains islands of $\alpha$-phase particles (phase $\mathrm{C}$ in Figure 5a). This divorced form, whose
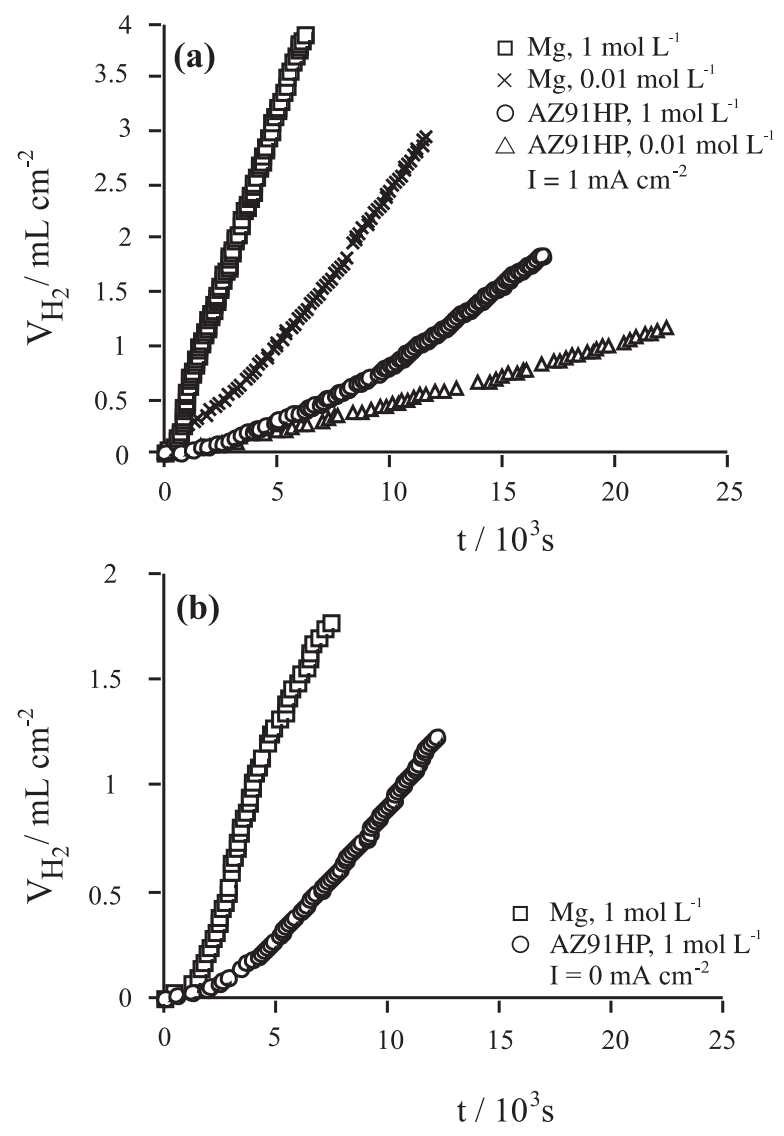

Figure 4. Hydrogen evolution during galvanostatic tests with $\mathrm{Mg}$ and with the AZ91HP alloy: (a) at $\mathrm{I}=1 \mathrm{~mA} \mathrm{~cm}-2$ in $0.01 \mathrm{~mol} \mathrm{~L}^{-1}$ and $1 \mathrm{~mol} \mathrm{~L}^{-1} \mathrm{NaCl}$, and (b) at the corrosion potential in $1 \mathrm{~mol} \mathrm{~L}^{-1} \mathrm{NaCl}$.

formation is favored by slow air-cooling, was commonly surrounded by bands of lamellae (phase B, point 3, with 34.8 wt.\% Al, Figure 5a).

The precipitation of the $\beta-\mathrm{Mg}_{17} \mathrm{Al}_{12}$ phase out of the $\alpha$ matrix can also occur by a mode of transformation, known as cellular precipitation or discontinuous precipitation, where $\alpha^{\prime} \rightarrow \alpha+\beta$ ( $\alpha^{\prime}$ : is the supersaturated matrix, $\alpha$ : is the same phase but with a lower thermodynamic excess of

Table 2. Current densities calculated from the volumetric tests in $1 \mathrm{~mol} \mathrm{~L}^{-1} \mathrm{NaCl}$ solutions and the factor $k$

\begin{tabular}{|c|c|c|c|c|c|}
\hline Metal & $\begin{array}{c}I^{\mathrm{a}} \\
\left(m A \mathrm{~cm}^{-2}\right)\end{array}$ & $\begin{array}{c}I_{\mathrm{H}_{2} \mathrm{Vol}}^{\mathrm{b}} \\
\left(\mathrm{mA} \mathrm{cm}^{-2}\right)\end{array}$ & $\begin{array}{c}I_{H_{2 p p i t}}{ }^{c} \\
\left(m \mathrm{~cm}^{-2}\right)\end{array}$ & $\begin{array}{l}\text { Current pair for } k \\
\text { calculation }\left(\mathrm{mA} \mathrm{cm}^{-2}\right)\end{array}$ & $k^{\mathrm{d}}$ \\
\hline \multirow[t]{5}{*}{$\mathrm{Mg}$} & $0\left(\mathrm{E}_{\text {corr }}\right)$ & -2.1 & -1.7 & & \\
\hline & 1 & -5.7 & -4.3 & 0 and 1 & 0.78 \\
\hline & 4 & -8.7 & -5.9 & 1 and 4 & 0.50 \\
\hline & 8 & -11.7 & -9.7 & 4 and 8 & 0.43 \\
\hline & 12 & -16.3 & -15.3 & 8 and 12 & 0.54 \\
\hline \multirow[t]{5}{*}{ AZ91HP } & $0\left(\mathrm{E}_{\text {corr }}\right)$ & -0.2 & -0.06 & & \\
\hline & $1^{\text {corr' }}$ & -0.6 & -0.5 & 0 and 1 & 0.31 \\
\hline & 4 & -1.6 & -1.7 & 1 and 4 & 0.25 \\
\hline & 8 & -3.7 & -4.1 & 4 and 8 & 0.34 \\
\hline & 12 & -5.9 & -6.3 & 8 and 12 & 0.35 \\
\hline
\end{tabular}

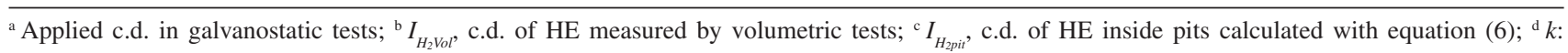
Calculated with equation (8a). 
solute, and $\beta$ : is the equilibrium precipitate). Morphologically this transformation is very similar to the eutectoid reaction ${ }^{24}$ and cellular precipitation and lamellar eutectic phase can only be distinguished by the Al-content of the $\alpha$-lamellae. The lamellar region shown in Figure 5a (Point 5) has $13.6 \mathrm{wt} . \% \mathrm{Al}$ and therefore represents a region of cellular precipitation.

Moreover, EDS-analyses confirmed the presence of manganese rich precipitates (point 4 in Figure 5a), which frequently showed a crystallographic shape.

\section{Morphology of attack}

The surfaces of the AZ91HP alloy and of Mg after the exposure to air-saturated $1 \mathrm{~mol} \mathrm{~L}^{-1} \mathrm{NaCl}$ solution under galvanostatic anodic polarization are shown in Figure 5b, $5 \mathrm{c}$ and 6 . The evaluation of the pitting morphology was difficult, as the pits are generally covered with corrosion products. The attacked surface of Mg (Figure 6a) showed deep parallel crevices, and Tunold ${ }^{2}$ described the same type of attack as responsible for exfoliation and spalling after longer exposure. The unattacked surface of the specimen was covered by a passive film, which consists of needles, perpendicular to the surface, with a diameter around $50 \mathrm{~nm}$ (Figure 6b).

In order to verify the correlation between corrosion attack and microstructure, corrosion tests were performed with slightly etched specimens, for which the microstructure was clearly revealed. ${ }^{25}$ As the nucleation of pits was slow, this generally leads to the formation of a few and very coarse pits, which makes difficult the identification of the attacked sites with respect to the microstructure.

In the present work, galvanostatic tests in aerated 1 mol L ${ }^{-1} \mathrm{NaCl}$ solution were also performed, and in part of them the applied current density was interrupted periodically (20 s with $I=2 \mathrm{~mA} \mathrm{~cm} \mathrm{~cm}^{-2}, 10 \mathrm{~s}$ interruption, $20 \mathrm{~s}$ with $I=2 \mathrm{~mA} \mathrm{~cm}^{-2} \mathrm{etc}$.). This forces the renucleation of pits after every interruption and leads to the formation of smaller and numerous pits.

The attack shown in Figure 5c represents obviously an attack in the $\alpha$-phase, since the neighboring grain is a lamellar phase, i.e., eutectic phase or cellular precipitation. In Figure $5 b$ the attack occurred probably in the lamellar phase, which can be deduced from the shape of the attacked phase (compare the shape of the attack in Figure $5 \mathrm{~b}$ with the lamellar phase in Figure 5a).

\section{Raman spectroscopic investigation of corrosion products}

Raman spectra were acquired from the specimen corroded in potentiodynamic tests in $1 \mathrm{~mol} \mathrm{~L}^{-1} \mathrm{NaCl}$. Both
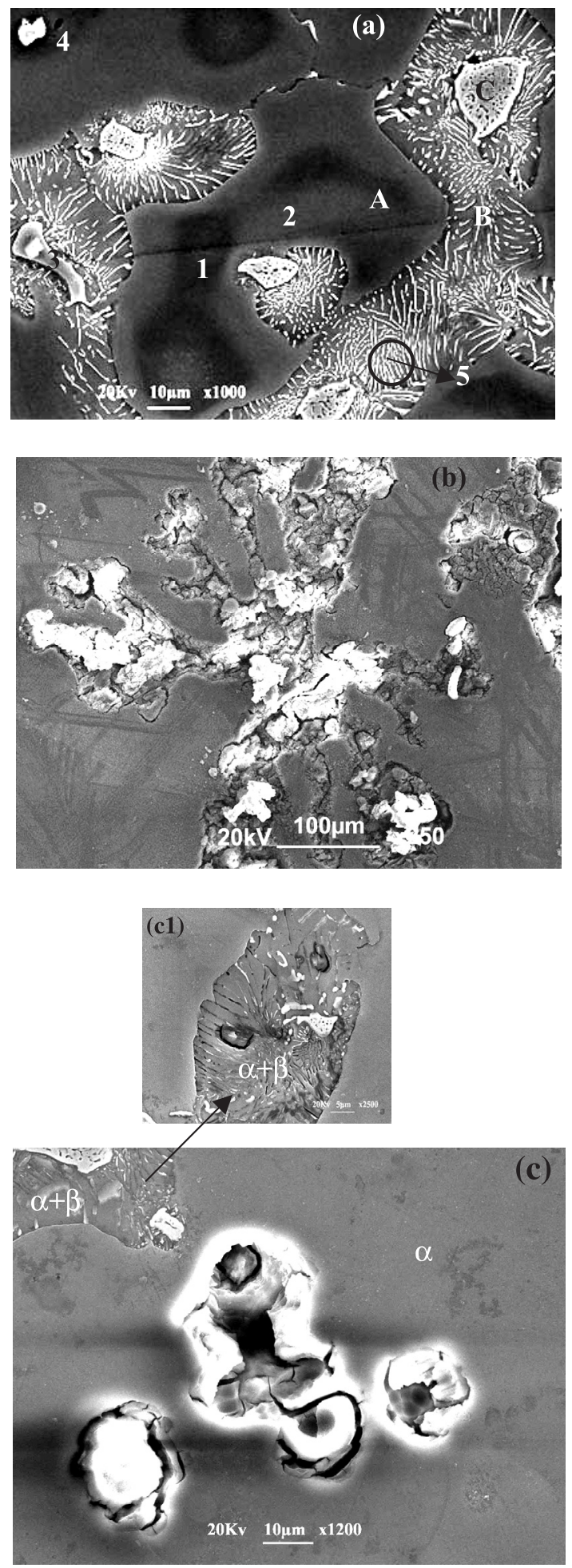

Figure 5. (a) SEM- view of the microstructure of AZ91HP alloy after micro-etching (etchant: $95 \mathrm{~mL}$ alcohol and $5 \mathrm{~mL}$ ethanoic acid solution, etching time: $\left.50 \mathrm{~s}^{25}\right)((\mathbf{A}) \alpha$ - phase, $(\mathbf{B}, \mathbf{5})$ bands of lamellar eutectic phase, $(\mathbf{C}, \mathbf{3})$ divorced eutectic phase: massive $\beta$ - phase with islands of $\alpha$-phase), (4) manganese rich precipitate, $(\mathbf{1}, \mathbf{2})$ area of coring; (b) SEM- view of corroded surface of AZ91HP in $1 \mathrm{~mol} \mathrm{~L}^{-1}$ $\mathrm{NaCl}$ (saturated with air) after anodic galvanostatic test with constant current; (c) SEM-view of the corroded surface of AZ91HP alloy after galvanostatic test performed with periodically interrupted current densities in $1 \mathrm{~mol} \mathrm{~L}^{-1} \mathrm{NaCl}$ electrolyte. 

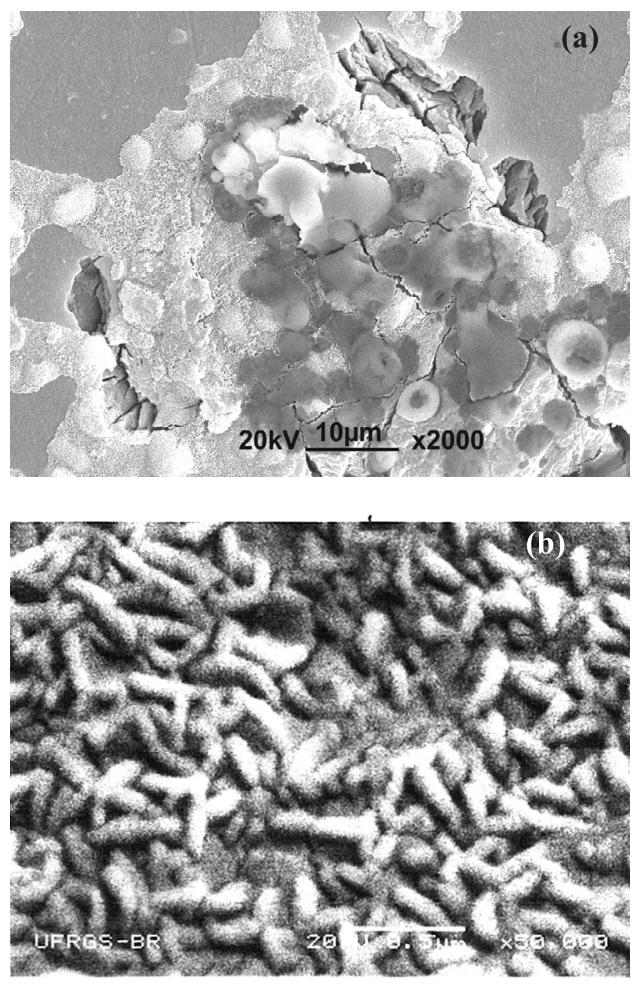

Figure 6. (a) SEM- view of corroded surface of pure Mg after anodic galvanostatic test in $1 \mathrm{~mol} \mathrm{~L}^{-1} \mathrm{NaCl}$ solution, saturated with air, and (b) platelet-like structure of the passive layer on pure $\mathrm{Mg}$.

magnesium and AZ91HP alloy showed two weak peaks and 1079.5 and $435.5 \mathrm{~cm}^{-1}$, respectively at 1079.5 and $438.5 \mathrm{~cm}^{-1}$ (Figure 7). A third peak was observed at 266 $\mathrm{cm}^{-1}$ (AZ91HP) and at $373 \mathrm{~cm}^{-1}(\mathrm{Mg})$ and the Raman data for some possible corrosion products are listed in Table 3 . The peak at $1079.5 \mathrm{~cm}^{-1}$ is very close to that of $\mathrm{MgCO}_{3}$ (about $\left.1093 \mathrm{~cm}^{-1}\right)^{26,27}$ and also to $\mathrm{MgO}\left(1074 \mathrm{~cm}^{-1}\right) .^{28}$ According to the literature, pure $\mathrm{MgO}$ powder should have an almost featureless Raman spectrum. However, a broad peak or shoulder at $c a .1074 \mathrm{~cm}^{-1}$ was sometimes reported..$^{28}$ The peak at $438.5 \mathrm{~cm}^{-1}(\mathrm{Mg})$ and $435.5 \mathrm{~cm}^{-1}$ (AZ91HP) is in good agreement with the strongest peak of the $\mathrm{Mg}(\mathrm{OH})_{2}$ (brucite). ${ }^{29}$ The peaks at $1079.5 \mathrm{~cm}^{-1}$ and at $438.5 \mathrm{~cm}^{-1}$ for magnesium remained present even when the spectrum was taken outside the pitted area, indicating the precipitation of corrosion products outside the pits, which was confirmed by microscopic investigations (Figure 6b).

\section{Discussion}

\section{Mechanism of the negative-difference effect}

Volumetric measurements with $\mathrm{Mg}$ and $\mathrm{Mg}$ alloys have been made by Tunold et $a l .{ }^{2}$ and by Song et al. ${ }^{4,19}$ however, they did not distinguish between hydrogen evolved inside
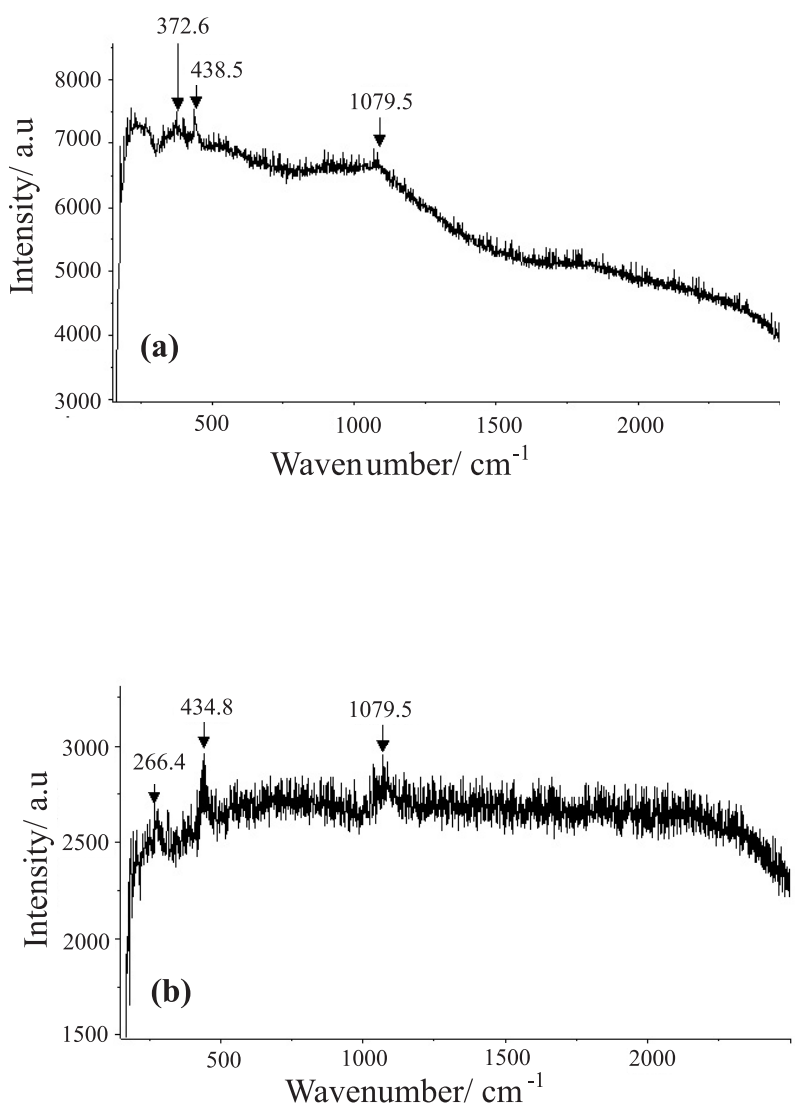

Figure 7. The Raman spectra of corrosion products: (a) $\mathrm{Mg}$ and (b) AZ91HP alloy.

Table 3. The $\mu$-Raman data of the corroded Mg and AZ91HP alloy surfaces and of possible corrosion products

\begin{tabular}{lll}
\hline Substance & Reference & Peaks/cm \\
\hline Products on $\mathrm{Mg}$ & this work & $373,438.5,1079.5$ \\
Products on $\mathrm{AZ91HP}$ & this work & $266,435.5,1079.5$ \\
Magnesite, $\mathrm{MgCO}_{3}$ & 26 & $212,331,738,1093$, \\
& & 1403,1758 \\
$\mathrm{Brucite}_{\mathrm{Mg}(\mathrm{OH})_{2}}$ & 27 & $176,298,727,1097$ \\
$\mathrm{MgO}_{\mathrm{MgCl}}$ & 28 & 282,445 \\
\hline
\end{tabular}

and outside the pits. The results reported here are in agreement with the results of Tunold, in the sense that the value of $k$ measured for $\mathrm{Mg}$ was greater than the value of $k$ for MgAlZn-alloy (AZ63) similar in composition to AZ91HP. Tunold et al. ${ }^{2}$ found $k>1$ in some cases for Mg, which would be incompatible with the model of $\mathrm{Mg}$ dissolution via $\mathrm{Mg}^{+}$. However, it can be assumed that only the hydrogen generated inside the pits is directly coupled 
with the mechanism of $\mathrm{Mg}$ dissolution, whereas the hydrogen reduction outside the pits is independent of this mechanism. This demonstrates the necessity for separating the two types of hydrogen evolution in order to understand the mechanism of pitting corrosion in $\mathrm{Mg}$ and its alloys.

From the results of the volumetric tests it was possible to deduce that the occurrence of pitting corrosion was much more severe for $\mathrm{Mg}$ than for the AZ91HP alloy. The corrosion rate of the metal was increased in the case of pitting due to the high current density of hydrogen reduction inside the pits. About $50 \%\left(I_{H_{2} p i t}=-0.50 \bullet I_{M g}\right)$ of the anodic current density was compensated by this cathodic partial reaction, which is presumably coupled to the $\mathrm{Mg}$ dissolution during pitting. In the case of the AZ91HP alloy, only about $30 \%$ of the anodic current density was compensated by hydrogen evolution inside the pits $\left(I_{H_{2} p i t}=-0.30 \bullet I_{M g}\right)$. As the corresponding value of $k$ for aluminum and $\mathrm{Al}$ alloys is $0.11-0.17$, the decrease of $k$ for AZ91HP alloy probably indicates an influence of the $\mathrm{Al}$ alloying element on the pitting behavior of the AZ91HP alloy. This shows also the potential for further improvement in the corrosion resistance that can still be achieved by further reducing the hydrogen reduction inside the pits.

\section{Correlation between microstructure and corrosion attack}

A correlation between microstructure and corrosion attack in the AZ91HP alloy was discussed ${ }^{4,21}$ and as Al is more resistant and has a higher pitting potential, a preferential attack of the $\alpha$-phase (Figure 5c) was assumed, although this was not directly confirmed by microscopic investigations. The pitting potentials for $\mathrm{Mg}$ and the alloy with 9 wt.\% of $\mathrm{Al}$ did not differ significantly, i.e. they did not show an influence of the $\mathrm{Al}$ content. However, as the tests should register the pitting potential of the most susceptible phase, they hardly reveal differences in the corrosion resistance of the phases.

The phases of the AZ91HP alloy with the lowest Al content should be the lamellae of $\alpha$-phase in the cellular precipitation and the center of the cored $\alpha$-grains. The corrosion tests in this work showed an attack to the $\alpha$ matrix, which occurred more in the center than at the grain boundaries, and it could be also observed an attack to the lamellar phase. The fact that this latter phase is sometimes attacked or not, can be related to the fact that the lamellar $\alpha$-phase can be $\alpha$-supersaturated in the eutectic or $\alpha$ - Aldepleted from cellular precipitation. An early stage of the attack, where lamellae of the $\beta$-phase remain still not attacked, was not detected. Therefore, a preferential attack to the $\alpha$-lamellae could not be directly confirmed. At a later stage, this observation is usually obstructed by the huge quantity of corrosion products.

\section{Conclusions}

The concept that the current density of hydrogen evolution inside pits is proportional to the current density of magnesium dissolution by pitting $\left(I_{H_{2} p i t}=-k \cdot I_{M_{g}}\right)$ is applicable to magnesium and AZ91HP alloy in $1 \mathrm{~mol} \mathrm{~L}^{-1}$ $\mathrm{NaCl}$ solution. The constant $k$ is about 0.30 for AZ91HP and 0.50 for magnesium, independent of the applied current.

The lower $k$ value for the AZ91HP-alloy is one reason for its better corrosion resistance, compared to magnesium, since in the case of pitting, about $50 \%$ of the anodic current was compensated by hydrogen evolution inside the pits for magnesium, and only about $30 \%$ for AZ91HP. Thus, pitting corrosion of magnesium has a stronger autocatalytic character.

The measurement of pitting potentials of $\mathrm{Mg}$ and AZ91HP alloy did not reproduce well the difference in the corrosion behavior of both materials. Potentiodynamic tests, revealing differences in the pit nucleation rate, were a better indicator for the corrosion behavior of $\mathrm{Mg}$ and the alloy.

\section{Acknowledgements}

The authors gratefully acknowledge financial support of CNPq for this research. The authors wish to thank the Microscopy Center of the Federal University of Rio Grande do Sul for the use of its facilities.

\section{References}

1. Bühler, K.; Metall 1990, 44, 748.

2. Tunold, R.; Holtan, H.; Hägg Berge, M.B.; Lasson, A.; SteenHansen, R.; Corros. Sci. 1977, 17, 353.

3. Emley, E.F.; Principles of Magnesium Technology, Pergamon Press: London, 1966.

4. Song, G.; Atrens, A.; Wu, X.; Zhang, B.; Corros. Sci. 1998, 40, 1769.

5. Miller, P.L.; Shaw, B.A.; Wendt, R.G.; Moshier, W.C.; Corrosion 1995, 51, 922.

6. King, P.F.; J. Electrochem. Soc. 1966, 113, 536.

7. Przyluski, J.; Palka, E.; Electrochim. Acta 1970, 15, 853.

8. Straumanis, M.E.; Bhatia, B.K.; J. Electrochem. Soc. 1963, 110, 357.

9. James, W.J.; Straumanis, M.E.; Bhatia, B.K.; J. Electrochem. Soc. 1963, 110, 1117.

10. Maker, G.L.; Kruger, J.; J. Electrochem. Soc. 1990, 137, 414.

11. Perrault, G.G.; J. Electroanal. Chem. 1970, 27, 47. 
12. Nazarov, A.P.; Yurasova, T.A.; Proceedings of Eurocorr '91; Budapest, October, 1991.

13. Nazarov, A.P.; Yurasova, T.A.; Zashch. Met. 1991, 27, 10.

14. Kaesche, H.; Z. Phys. Chem. 1960, 26, 138.

15. Edeleanu, C.; Evans, U.R.; Trans. Faraday Soc. 1951, 47, 1121.

16. Richardson, J.A.; Wood, G.C.; Corros. Sci. 1970, 10, 313.

17. Knörnschild, G.; Kaesche, H.; Int. Symp. On Pits and Pores, Formation, Properties and Significance for Advanced Luminescent Materials; 192th Meeting of The Electrochem. Society, Montreal, May, 1997.

18. Pickering, H.W.; Frankenthal, R.P.; J. Electrochem. Soc. 1972, 119, 1297.

19. Song, G.; Atrens, A.; St. John, D.; Nairn, J.; Li, Y.; Corros. Sci. 1997, 39, 855.

20. Müller I.L.; Galvele, J.R.; Corros. Sci. 1977, 17, 995.

21. Ambat, R.; Anng, N.N.; Zhou, W.; J. Appl. Electrochem. 2000, 30,865 .

22. Kajita, T.; Metalurgia 1967, 23, 837.

23. Magnesium Alloys, Metallography and Microstructures-ASM HANDBOOK, vol. 9, $5^{\text {th }}$ ed., ASM International: USA, 1992, p. 425 .
24. Porter, D. A ; Easterling, K. E.; Phase Transformations in Metals and Alloys, $5^{\text {th }}$ ed., Chapman \& Hall: London, 1981.

25. Schaberger, E.; Kahn, D.; Lang, M.; Prakt. Metallogr. 1998, $35,305$.

26. http://minerals.gps.caltech.edu/files/raman/index.htm, accessed in January 2002. Raman Spectra, acquired at the California Institute of Technology, Pasadena, California, USA.

27. http://www.fis.unipr.it/ bersani/raman/index2.htm, accessed in January 2002. Raman Spectra of minerals, collected at the Department of Physics, University of Parma.

28. Fang, H.; Smith, B.; Cross-cut Lean Exhaust Emissions Reduction Simulations Detroit, Michigan, CLEERS WORKSHOP, 2001.

29. http://staff.aist.go.jp/y.iida/E-index.htm, accessed in January 2002. Raman Spectra, database of Minerals and Inorganic Materials, collected at the National Institute of Advanced Industrial Science and Technology (AIST), Japan.

30. Weckhuysen, B. M.; Mestl, G.; Rosynek, M. P.; Krawietz, T. R.; Haw, J. F.; Lunsford, J. H. J. Phys. Chem. B, 1998, 19, 2.

Received: February 4, 2003 Published on the web: August 12, 2003 